\title{
Use of pessary in the treatment of pelvic floor dysfunctions: a systematic review
}

\author{
DOI: https://doi.org/10.5114/pq.2018.74704
}

\author{
Karoline Scarabelot', Franciele Pereira', Luana Ghizzo', Jéssica Willing², Janeisa Virtuoso' \\ ${ }^{1}$ Federal University of Santa Catarina, Florianópolis, Brazil \\ ${ }^{2}$ Federal University of Health Sciences of Porto Alegre, Porto Alegre, Brazil
}

\section{Abstract}

Introduction. To describe and evaluate the scientific evidence on the use of pessary in the treatment of pelvic floor dysfunctions. Methods. This systematic review was performed in accordance with the Preferred Reporting Items for Systematic Reviews and Meta-Analyses (PRISMA) guidelines. The databases searched were ScienceDirect, PubMed, PEDro, and BVS. The following descriptors were used: 'clinical trial,' 'pessary,' 'pelvic floor,' and the Boolean operator 'and.' The search was conducted between November 2016 and February 2017. The methodological quality of the selected articles was analysed with the Physiotherapy Evidence Database (PEDro) scale.

Results. After the insertion of the filters in the databases, 379 titles were selected, of which 5 articles were picked out in pairs for analysis as a whole. The 3 studies investigating the use of pessary in the treatment of pelvic organ prolapse included women with prolapse stages II-III. The rings or Gellhorn pessaries were the most frequently used, and all showed benefits in decreasing urinary symptoms and improvement of prolapse.

Conclusions. The pessary is beneficial for the treatment of urinary incontinence and pelvic organ prolapse. Good methodological quality was also identified in most studies included.

Key words: pelvis diaphragm, conservative treatment, clinical trial

\section{Introduction}

Pelvic floor dysfunctions occur owing to injuries and deterioration of muscles, nerves, and connective tissues that support and control normal pelvic function [1]. They constitute a complex condition that may be asymptomatic or involve symptoms of anorectal dysfunction, urinary dysfunction, and/or pelvic organ prolapse (POP) [2]. The prevalence rates of pelvic floor dysfunctions vary depending on the methodology adopted in a particular study, and urinary incontinence (UI) and POP are the most well-known and high-prevalence dysfunctions, with rates increasing progressively with age [3].

There are different therapeutic methods that aim at improving these dysfunctions, such as electrostimulation, vaginal cones, biofeedback, pelvic floor muscle training (PFMT), and the use of pessaries [4-6]. Despite limited evidence, the pessary is commonly used in the treatment of genital prolapse and presented in $77 \%$ of cases as the first line treatment by the American Urogynecologic Society (AUGS) [7]. The pessaries are intravaginal devices made of silicone that must be introduced into the vagina for the purpose of supporting the pelvic organs [8].

It is estimated that a 79 -year-old woman has a $11-12 \%$ probability of undergoing prolapse correction surgery for UI and the probability of reoperation refers to $29.2 \%$ of cases [9]. Thus, the use of the pessary may become a temporary treatment option, providing a solution for women who have no indication for surgery, as a conservative treatment option [10].
Therefore, there is an evident need to group the scientific evidence that identifies the use of the pessary as a form of treatment of pelvic floor dysfunctions. The purpose of this systematic review is to describe and evaluate the scientific evidence on the use of pessary as a therapeutic method in pelvic floor dysfunctions.

\section{Subjects and methods}

This systematic review was performed in accordance with the Preferred Reporting Items for Systematic Reviews and Meta-Analyses (PRISMA) guidelines. The databases searched were ScienceDirect, PubMed, PEDro, and Virtual Health Library. The descriptors were: 'clinical trial,' 'pessary,' and 'pelvic floor'; the Boolean operator 'and' was applied. The search was conducted between November 2016 and February 2017.

For the systematic review, articles that met the following criteria were included: (1) clinical trial; (2) use of the pessary as a treatment method; (3) adult female participants; and (4) outcome for dysfunction of the pelvic floor muscles. We excluded studies whose treatment was based exclusively on surgical techniques and those written in languages other than English, Portuguese or Spanish.

First, two independent reviewers selected the studies based on the titles, excluding those clearly unrelated to the review theme. Afterwards, the selected titles had their summaries read to analyse the inclusion criteria. On the basis of the selected abstracts, the complete texts for analysis were

Correspondence address: address: Karoline Sousa Scarabelot, Federal University of Santa Catarina, Araranguá Campus, Araranguá, Brazil, Graduate Program in Health Sciences - Rod. Gov. Jorge Lacerda, 3201, Jardim das Avenidas - Araranguá - SC - CEP: 88.906-072, e-mail: karoline.scarabelot@posgrad.ufsc.br 
Table 1. The PEDro scale

\begin{tabular}{|r|l|}
\hline 1 & Eligibility criteria were specified \\
\hline 2 & $\begin{array}{l}\text { Subjects were randomly allocated to groups (in a crossover study, subjects were randomly allocated in the order } \\
\text { in which treatments were received) }\end{array}$ \\
\hline 3 & Allocation was concealed \\
\hline 4 & The groups were similar at baseline regarding the most important prognostic indicators \\
\hline 5 & There was blinding of all subjects \\
\hline 6 & There was blinding of all therapists who administered the therapy \\
\hline 7 & There was blinding of all assessors who measured at least one key outcome \\
\hline 8 & Measures of at least one key outcome were obtained from more than 85\% of the subjects initially allocated to groups \\
\hline 9 & $\begin{array}{l}\text { All subjects for whom outcome measures were available received the treatment or control condition as allocated or, } \\
\text { where this was not the case, data for at least one key outcome were analysed by 'intention to treat' }\end{array}$ \\
\hline 10 & The results of between-group statistical comparisons were reported for at least one key outcome \\
\hline 11 & The study provided both point measures and measures of variability for at least one key outcome \\
\hline
\end{tabular}

read. Possible disagreements during the process were resolved by consensus among the reviewers.

The methodological quality of the selected articles was analysed with the Physiotherapy Evidence Database (PEDro) scale (Table 1), consisting of 11 items, out of which 10 scored.

Each item on the scale was scored according to its presence $(P)$ or absence $(A)$ in the assessed study. For each present item, a point was assigned (with the exception of the first item). The items that were not described in the studies were classified as 'not described' $(N)$ and did not receive scores. The final score was obtained by adding all the items present. The articles indexed in the PEDro database that already presented evaluation of methodological quality by PEDro members had their score maintained; those non-indexed were evaluated independently by two reviewers in pairs.
For the data management, a qualitative synthesis was performed and the following information was extracted from the selected studies: (1) author (year), country; (2) type of study; (3) characteristics of the sample; (4) characteristics of the interventions; (5) main outcomes; and (6) main results.

This systematic review was recorded in the International Prospective Register of Systematic Reviews (PROSPERO) under the number CRD42017062606.

\section{Results}

In relation to the number of trials identified for the systematic review, as presented in Figure 1, after an insertion of the filters into the databases, 379 titles were selected. Among these, 15 were duplicates or removed articles, so 364 titles
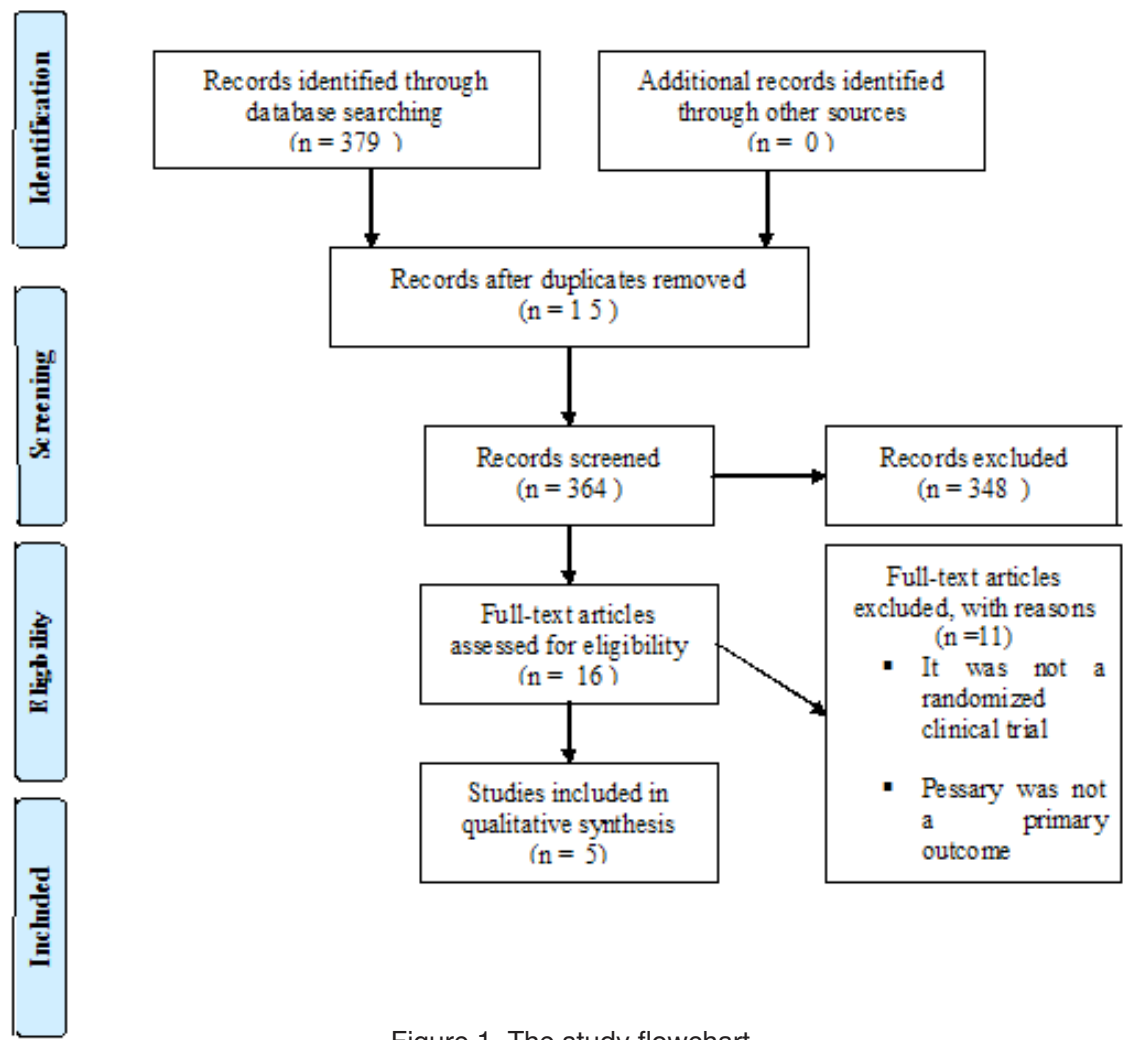
remained for the reading. After paired reading, 5 studies were considered potentially relevant for index trials, all of which were selected for the review analysis.

The results of the systematic review are presented in Table 2, describing the studies that met the eligibility criteria. Below, there is also a descriptive summary of the information collected in the mentioned studies, in addition to the analysis of their quality with the PEDro scale.

The 3 studies that investigated the use of pessary in the treatment of POP included women with degrees of prolapse ranging from I to III $[6,7,11]$. The other studies $[12,13]$ eval- uated the use of pessary in UI and recruited women with both stress $\mathrm{UI}$ and overactive bladder.

As for instruments to evaluate the obtained results, Barber et al. [11], Cheung et al. [6], and Cundiff et al. [7] applied the following validated questionnaires for prolapse quantification, dysfunction identification, and determination of impact on quality of life, respectively: Pelvic Organ Prolapse Questionnaire (POPQ), Pelvic Floor Distress Inventory (PFDI), Pelvic Floor Impact Questionnaire (PFIQ). In turn, Kondo et al. [13] employed the urodynamic test, pad test, and a questionnaire prepared by the researchers to collect data regarding

Table 2. Results for the articles included in the review $(n=5)$

\begin{tabular}{|c|c|c|c|c|c|}
\hline $\begin{array}{l}\text { Author } \\
\text { (year), } \\
\text { country }\end{array}$ & $\begin{array}{l}\text { Kind } \\
\text { of study }\end{array}$ & Sample characteristics & Intervention & Main outcomes & Main results \\
\hline $\begin{array}{l}\text { Barber et al. } \\
(2006) \\
\text { USA [11] }\end{array}$ & $\begin{array}{l}\text { Multicentre } \\
\text { randomized } \\
\text { clinical trial }\end{array}$ & $\begin{array}{l}\text { Women who presented } \\
\text { symptomatic pelvic organ } \\
\text { prolapse over the age of } \\
18 \text { years. Surgery group: } \\
64 \text { women with prolapse } \\
\text { stage III or more. } \\
\text { Pessary group: } 42 \text { women } \\
\text { with prolapse stage II or more }\end{array}$ & $\begin{array}{l}\text { Surgery group: reconstructive } \\
\text { surgery. Pessary group: use } \\
\text { of the ring pessary for } 3 \text { months }\end{array}$ & $\begin{array}{l}\text { Both groups used POPQ; PFDI, } \\
\text { formed by } 3 \text { scales: POPDI } \\
\text { (evaluates the prolapse), } \\
\text { UDI (evaluates urinary symptoms), } \\
\text { and CRADI (evaluates the colorec- } \\
\text { tal). PFIQ, formed by } 3 \text { POPIQ } \\
\text { scales (evaluates the impact } \\
\text { of prolapse); UIQ (urinary impact) } \\
\text { and CRAIQ (colorectal-anal } \\
\text { impact). The pessary group } \\
\text { also used VAS of satisfaction } \\
\text { with the use of pessary. Both } \\
\text { groups made the application } \\
\text { at the beginning. The pessary } \\
\text { group reapplied the instruments } \\
\text { after using each pessary for } \\
3 \text { months and the surgery group } \\
\text { after } 6 \text { months of PO }\end{array}$ & $\begin{array}{l}\text { Group characteristics: no difference } \\
\text { between groups in the proportion } \\
\text { of women with urinary incontinence } \\
(p=0.93) \text {, faecal incontinence } \\
(p=0.80) \text {, or constipation }(p=0.84) \text {. } \\
\text { The mean prolapse scores, urinary } \\
\text { symptoms, PFDI colorectal, and } \\
\text { PFIQ of the pessary and surgery } \\
\text { groups were similar ( } p<0.001) \text {. } \\
\text { Pessary group: a significant improve- } \\
\text { ment in prolapse and urinary PFDI } \\
\text { symptoms after } 3 \text { months of treat- } \\
\text { ment with one pessary ( } p<0.001) \\
\text { for each. The PFDI colorectal scale } \\
\text { ( } p=0.14) \text { and each of the } 3 \text { PFIQ } \\
\text { scales did not show significant chang- } \\
\text { es (POPIQ: } p=0.08, \text { UIQ: } p=0.88 \text {, } \\
\text { CRAIQ: } p=0.80) \text {. A significant posi- } \\
\text { tive correlation with satisfaction } \\
\text { from using pessary ( } p<0.0001) \text {. } \\
\text { Surgery group: a significant im- } \\
\text { provement in the prolapse, urinary, } \\
\text { and colorectal symptoms of PFDI } \\
\text { and PFIQ } 6 \text { months after recon- } \\
\text { structive surgery }(p<0.001 \text { for all) }\end{array}$ \\
\hline $\begin{array}{c}\text { Cheung et al. } \\
\text { (2016), } \\
\text { China [6] }\end{array}$ & $\begin{array}{l}\text { Randomized } \\
\text { controlled } \\
\text { trial }\end{array}$ & $\begin{array}{l}\text { Women with symptomatic } \\
\text { prolapse stages I-III, without } \\
\text { previous treatment. } \\
\text { Both groups had a mean age } \\
\text { of } 62 \text { years. Control group: } \\
137 \text { patients. Pessary group: } \\
139 \text { patients }\end{array}$ & $\begin{array}{l}\text { Control group: women } \\
\text { instructed by nurses to } \\
\text { practice PFMT with } 8-10 \\
\text { exercises per session with } \\
\text { 8-12 repetitions each, } \\
\text { performed at least } 2 \text { times } \\
\text { a day and } 3 \text { days a week. } \\
\text { Pessary group: PFMT + ring } \\
\text { pessary for } 6 \text { months }\end{array}$ & $\begin{array}{l}\text { VAS for prolapse symptoms; } \\
\text { POP-Q; PFIQ; PFDI. Applied } \\
\text { at baseline, after } 6 \text { months, } \\
\text { and after } 12 \text { months in both } \\
\text { groups }\end{array}$ & $\begin{array}{l}\text { Control group: } 94 \% \text { comfortable } \\
\text { with the treatment, at } 6 \text { and } 12 \\
\text { months } 88 \% \text { remained on conser- } \\
\text { vative treatment. Pessary group: } \\
66 \% \text { comfortable with the pessary, } \\
\text { after } 6 \text { months } 63 \% \text { of them main- } \\
\text { tained the pessary, after } 12 \text { months } \\
60 \% \text {. Pelvic floor exercise was taught } \\
\text { to all participants in the groups; } \\
39.2 \% \text { in the pessary group and } \\
49.3 \% \text { in the control group under- } \\
\text { went training at least twice a day, } \\
3 \text { days a week. No significant } \\
\text { difference between the two groups. } \\
\text { After } 6 \text { months of treatment, the } \\
\text { difference between the groups in } \\
\text { the PFDI was: POPDI: } p=0.02 \text {, } \\
\text { UDI: } p=0.87, \text { CRADI: } p=0.92 \text { in } \\
\text { relation to PFIQ: POPIQ: } p=0.22 \text {, } \\
\text { UIQ: } p=0.33, \text { CRAIQ: } p=0.90 \text {. } \\
\text { After } 12 \text { months of treatment, the } \\
\text { difference between the groups of } \\
\text { the PFDI was: POPDI: } p=0.04 \text {, } \\
\text { UDI: } p=0.57 \text {, CRADI: } p=0.80 \text { in } \\
\text { relation to PFIQ: POPIQ: } p=0.02 \text {, } \\
\text { UIQ: } p=0.71, \text { CRAIQ: } p=0.77 \text {. } \\
\text { VAS scores decreased in the pes- } \\
\text { sary at } 6 \text { and } 12 \text { months ( } p<0.01 \text { ) } \\
\text { but no difference in the control } \\
\text { group ( } p=0.14 \text { ) }\end{array}$ \\
\hline
\end{tabular}




\begin{tabular}{|c|c|c|c|c|c|}
\hline $\begin{array}{l}\text { Cundiff et al. } \\
\qquad(2007) \\
\text { USA [7] }\end{array}$ & $\begin{array}{l}\text { Randomized } \\
\text { multicentre } \\
\text { trial with } \\
\text { crossover }\end{array}$ & $\begin{array}{l}\text { Women who presented } \\
\text { symptomatic pelvic organ } \\
\text { prolapse stage II, with the } \\
\text { average age of } 61 \text { years. } \\
\text { Pessary group I: } 71 \text { patients. } \\
\text { Pessary group II: } 63 \text { patients }\end{array}$ & $\begin{array}{l}\text { Use of pessary for } 3 \text { months, } \\
\text { in both groups. Pessary group I: } \\
\text { ring pessary. Pessary group II: } \\
\text { Gellhorn pessary }\end{array}$ & POPQ; PFDI; PFIQ; SFQ & $\begin{array}{l}\text { In relation to the degree of prolapse, } \\
48 \% \text { were evaluated with stage II, } \\
42 \% \text { with stage III, and } 10 \% \text { with } \\
\text { stage IV. After pessary use, there was } \\
\text { a statistically significant change in } \\
\text { most of the PFDI and PFIQ scores. } \\
\text { Pessary group I (ring): PFIQ: } p=0.03 \text {, } \\
\text { POPDI: } p=0.25, \text { CRADI: } p=0.26 \\
\text { compared with PFIQ: POPIQ: } \\
p=0.33 \text {, UIQ: } p=0.68, \text { CRAIQ: } \\
p=0.79 . \text { Pessary group II (Gell- } \\
\text { honrn): PFDI: POPDI: } p=0.001, \\
\text { UDI: } p=0.001, \text { CRADI: } p=0.012 \\
\text { in relation to PFIQ: POPIQ: } \\
p=0.006, \text { UIQ: } p=0.38, \text { CRAIQ: } \\
p=0.17\end{array}$ \\
\hline $\begin{array}{l}\text { Kondo et al. } \\
\text { (1997), } \\
\text { Japan [13] }\end{array}$ & Clinical trial & $\begin{array}{l}77 \text { women, } 57 \text { of whom } \\
\text { presented SUI and } 20 \text { UUI, } \\
\text { with the average age } \\
\text { of } 53 \text { years }\end{array}$ & $\begin{array}{l}\text { Patients received a video } \\
\text { on the vaginal ring pessary } \\
\text { guidelines. The choice of the } \\
\text { pessary size was made by } \\
\text { a professional, as well as } \\
\text { the instruction for placement } \\
\text { and removal of the pessary. } \\
\text { Women instructed to make } \\
5 \text { visits during the } 12 \text {-week trial. } \\
\text { They were evaluated before } \\
\text { and after the intervention }\end{array}$ & $\begin{array}{l}\text { Presence of urinary incontinence: } \\
\text { episodes and quantity objective } \\
\text { urinary loss; urinary flow and } \\
\text { residual volume. All evaluations } \\
\text { were performed before and } \\
\text { after the use of the device. } \\
\text { At the end of } 12 \text { weeks, VAS: } \\
\text { the patients indicated the level } \\
\text { of facility with the insertion } \\
\text { and removal of the pessary }\end{array}$ & $\begin{array}{l}\text { The } 4 \text { subjective evaluations, } \\
\text { the pad test, and the residual urine } \\
\text { declined significantly while the peak } \\
\text { and mean urine flow rates remained } \\
\text { unchanged. The amount of urine loss } \\
\text { decreased from } 20.6 \text { to } 4.8 \mathrm{~g} / \text { hour } \\
(p<0.001) \text {. Flow pressures remained } \\
\text { unchanged, suggesting that the } \\
\text { device did not disrupt the urinary } \\
\text { flow. Ease of insertion and removal } \\
\text { marked on VAS was } 21.9 \pm 3.5 \text { and } \\
36.1 \pm 4.5 \text {, respectively. This differ- } \\
\text { ence was significant ( } p<0.01) . \\
\text { Subjectively, } 22 \text { of } 77 \text { patients } \\
(29 \%) \text { reported continence and in } \\
39 \text { (51\%) the severity of incontinence } \\
\text { decreased by more than } 50 \%\end{array}$ \\
\hline $\begin{array}{l}\text { Richter et al. } \\
\quad(2010) \\
\text { USA [12] }\end{array}$ & $\begin{array}{l}\text { Randomized } \\
\text { clinical trial }\end{array}$ & $\begin{array}{l}\text { Women } 18 \text { years of age } \\
\text { or older, with SUI or UUI, } \\
\text { randomized into } 3 \text { groups. } \\
\text { Behavioural therapy - control } \\
\text { group: } n=146 \text {; pessary group: } \\
n=149 \text {; group that underwent } \\
\text { the two therapies: } n=151\end{array}$ & $\begin{array}{l}\text { Behavioural therapy group } \\
\text { (control): individual guidelines, } \\
\text { at } 4 \text { visits with a 2-week } \\
\text { interval, to perform exercises } \\
\text { for the pelvic floor muscles } \\
\text { and employ strategies for the } \\
\text { activation of these muscles in } \\
\text { order to prevent SUI and UUI. } \\
\text { Pessary group: ring or dish } \\
\text { pessary was chosen and } \\
\text { applied. Combined therapy } \\
\text { group: pessary and behavioural } \\
\text { guidelines. After } 8 \text { weeks, } \\
\text { the combined therapy and } \\
\text { behavioural therapy group were } \\
\text { encouraged to continue with } \\
\text { the exercises; the pessary } \\
\text { group and again the combined } \\
\text { therapy group were encouraged } \\
\text { to continue using the pessary }\end{array}$ & $\begin{array}{l}\text { All groups were evaluated } \\
3,6 \text {, and } 12 \text { months after } \\
\text { randomization. PGI-I to classify } \\
\text { symptom improvement as 'better' } \\
\text { or 'much better.' PFDI to indicate } \\
\text { no nuisance through the 'no' } \\
\text { response to the } 6 \text { items in the SUI } \\
\text { subscale. Urinary frequency } \\
\text { through urination diary (< } 14 \\
\text { episodes vs. } \geq 14 \text { episodes), } \\
\text { satisfaction with PSQ treatment }\end{array}$ & $\begin{array}{l}\text { The average of } 46 \% \text { of the } 3 \text { groups } \\
\text { reported being 'better' or 'much } \\
\text { better' (pessary: } 40 \% \text {, behavioural: } \\
49 \%, \text { combined therapy: } 53 \% \text { ) } \\
\text { at } 3 \text { months, with no statistically } \\
\text { significant difference between } \\
\text { pessary and behavioural groups. } \\
\text { The combined therapy group was } \\
\text { significantly higher than the pessary } \\
\text { group ( } p=0.02) \text {; } 33 \% \text { of the pes- } \\
\text { sary group and } 49 \% \text { of the behav- } \\
\text { ioural group reported no further SUI } \\
\text { (p= } 0.006) . \text { The combined therapy } \\
\text { group had a } 44 \% \text { discomfort im- } \\
\text { provement, which was significantly } \\
\text { different from the pessary group, } \\
\text { but not unlike the behavioural group } \\
\text { and no better than single therapy. } \\
\text { More women in the behavioural } \\
\text { group than in the pessary group } \\
\text { reported being satisfied with the } \\
\text { therapy at } 3 \text { months ( } 75 \% \text { vs. } 63 \% \text {, } \\
p=0.03 \text { ). Satisfaction with therapy } \\
\text { in the combination therapy group } \\
\text { was } 79 \%, \text { which did not differ from } \\
\text { the behavioural therapy. Patient } \\
\text { satisfaction at } 12 \text { months was } \\
50-54 \% \text { in intention-to-treat analysis } \\
\text { and } 85-91 \% \text { in protocol analysis, } \\
\text { without significant differences } \\
\text { between the groups. } 50 \% \text { of each } \\
\text { group showed a reduction of } 75 \% \\
\text { of urinary loss episodes }\end{array}$ \\
\hline
\end{tabular}

CRADI - Colorectal-Anal Distress Inventory 8, CRAIQ - Colorectal-Anal Impact Questionnaire, PFDI - Pelvic Floor Distress Inventory, PFIQ - Pelvic Floor Impact Questionnaire, PFMT - pelvic floor muscle training, PGI-I - Patient Global Impression of Improvement, PO - postoperative, POPDI - Pelvic Organ Prolapse Distress Inventory 6, POPIQ - Pelvic Organ Prolapse Impact Questionnaire, POP-Q - Pelvic Organ Prolapse Quantitation, POPQ - Pelvic Organ Prolapse Questionnaire, PSQ - Patient Satisfaction Questionnaire, SFQ - Sexual Function Questionnaire, SUI - stress urinary incontinence, UDI - Urinary Distress Inventory 6, UIQ - Urinary Impact Questionnaire, UUI - urgency urinary incontinence, VAS - visual analogue scale 
Table 3. PEDro scale evaluation

\begin{tabular}{|c|c|c|c|c|c|c|c|c|c|c|c|c|}
\hline \multirow[t]{2}{*}{ Study } & \multicolumn{12}{|c|}{ PEDro scale criteria } \\
\hline & 1 & 2 & 3 & 4 & 5 & 6 & 7 & 8 & 9 & 10 & 11 & Total \\
\hline Barber et al. [11] & $\mathrm{P}$ & A & A & A & A & A & $\mathrm{N}$ & $\mathrm{N}$ & $\mathrm{N}$ & $P$ & $\mathrm{P}$ & $2 / 11$ \\
\hline Cheung et al. [6] & $\mathrm{P}$ & $\mathrm{P}$ & $P$ & $\mathrm{P}$ & A & A & A & $\mathrm{P}$ & $\mathrm{P}$ & $P$ & A & $6 / 11$ \\
\hline Richter et al. [12] & $\mathrm{P}$ & $P$ & $P$ & $\mathrm{P}$ & A & A & $\mathrm{P}$ & $\mathrm{P}$ & $\mathrm{P}$ & $P$ & A & $7 / 11$ \\
\hline Cundiff et al. [7] & $\mathrm{P}$ & $P$ & $P$ & $P$ & A & A & A & $P$ & $\mathrm{P}$ & $P$ & $P$ & $7 / 11$ \\
\hline Kondo et al. [13] & & & & & & & & & & & & $7 / 11^{*}$ \\
\hline
\end{tabular}

$\mathrm{P}$ - presence of the criterion, $\mathrm{A}$ - absence of the criterion, $\mathrm{N}$ - criterion not described

* The study by Kondo et al. [13] had already been evaluated by the PEDro scale, as found in the PEDro database

the amount and episodes of urinary loss. Richter et al. [12] used validated questionnaires such as Patient Global Impression of Improvement (PGI-I), Pelvic Floor Distress Inventory (PFDI), and Patient Satisfaction Questionnaire (PSQ), as well as an urination diary.

\section{Subjective and objective results of urinary loss}

Urinary urgency, frequency of loss, and amount of loss were significantly reduced in the study by Kondo et al. [13] but the paper does not clarify how these parameters were evaluated.

In the study by Richter et al. [12], $50 \%$ of each group reported a $75 \%$ improvement in episodes of urinary loss, assessed by a voiding diary. In turn, Kondo et al. [13] measured the amount of urinary loss by means of a one-hour pad test, which showed a significant improvement after the intervention with a pessary, with a reduction from 20.6 to $4.8 \mathrm{~g}(p<0.001)$.

Pelvic floor disorders were evaluated in accordance with the PFDI. Thus, in the study by Barber et al. [11], the surgical method presented significant improvement on the prolapse, urinary and colorectal symptoms $(p<0.001$ for all), whereas the pessary group improved only in the urinary symptoms $(p<0.001)$.

Cheung et al. [6] observed improvement in prolapse with the use of the pessary after 6 and 12 months. In turn, Cundiff et al. [7] also found prolapse improvement in the group that applied a ring pessary, whereas in the Gellhorn pessary group there was a significant improvement in prolapse, colorectal symptoms, and urinary symptoms, respectively: Pelvic Organ Prolapse Distress Inventory (POPDI): $p=0.001$, Urinary Distress Inventory (UDI): $p=0.001$, Colorectal-Anal Distress Inventory (CRADI): $p=0.012$.

In the study by Barber et al. [11], the surgical method showed a positive impact on the quality of life when compared with the pessary group, and the study by Cheung et al. [6] identified that after 12 months of pessary use there was improvement in the prolapse stage. Similarly, in the study by Cundiff et al. [7], the group that used the ring pessary presented no significant difference and in the group that used the Gellhorn pessary there was a significant improvement in prolapse only, demonstrated by the Pelvic Organ Prolapse Impact Questionnaire (POPIQ) subitem.

\section{Satisfaction of patients with the therapy}

Barber et al. [11] noted that after 3 months of pessary therapy, there was improvement in patient satisfaction with the therapy. The findings of Richter et al. [12] identified that after 3 months of intervention the behavioural therapy group had a higher satisfaction than the pessary group, but after
12 months of therapy there was no difference between the groups.

Evaluation of the methodological quality of the studies

The evaluation of the quality of the studies included in the review with the PEDro scale proved that the studies by Cheung et al. [6], Richter et al. [12], Cundiff et al. [7], and Kondo et al. [13] reached $50-60 \%$ of the criteria required while the study by Barber et al. [11] met only 2 criteria.

Most studies demonstrated a reasonable quality, i.e. 4 of the 5 articles scored above 6 points, although they did not meet all the quality criteria for a randomized clinical trial. It can be observed that items 5, 6, and 7 were the least respected. Regarding items 5 and 6 , the difficulty of blinding the therapy is understood; in turn, in item 7, more effort could have been made so that the evaluator did not know the therapy applied to the participants. The methodological quality verification data are presented in Table 3.

A bias can be identified in the study by Barber et al. [11] since the women recruited for the research had different stages of prolapse in the surgery group compared with the pessary group.

\section{Discussion}

The present study indicates an improvement in the frequency of urinary loss, as well as the amount of the loss in the papers that evaluated the pessary as a form of treatment for UI. POP also showed improvement. The patients' satisfaction with the therapy was also reported. The reviewed articles demonstrate that the use of vaginal pessaries can be effective in the treatment of UI and POP.

In the studies evaluating the use of pessary for POP, the identified stage of prolapse was between degree II and degree III. Only the study by Cundiff et al. [7] involved women with degree IV of prolapse as $10 \%$ of the sample. These results corroborate those observed by Ding et al. [14], who identified $89 \%$ degree III prolapse and $11 \%$ degree IV in patients who applied a pessary. With these results, it was possible to conclude that the use of pessary has been shown to be successful in women with advanced stages of POP, although pessaries are theoretically recommended only for patients with early POP stages [14].

Regarding the most effective types of pessaries in the treatment of prolapse, the study by Cundiff et al. [7] identified improvement in prolapse symptoms only in the group that used Gellhorn pessaries. This partially corroborates the findings of the study by Ding et al. [14], who observed a positive correlation in the improvement of prolapse symp- 
toms after 3 months with the use of both pessaries: in $74.4 \%$ of patients for the ring pessary and in $25.6 \%$ of patients for the Gellhorn pessary. The Gellhorn-type pessary plays an important role in supporting the pelvic organ, since it has a solid composition and a rounded shape. It is able to fill all the passable organ escape spaces [15].

As for the techniques used in the treatment of prolapses, Barber et al. [11] identified a significant improvement in patients who underwent surgical repair when compared with the group treated with a ring pessary for 3 months. Similarly, Yeniel et al. [16] evaluated the difference in the pessary or surgery treatment of POP in symptomatic women; both groups obtained successful results.

When comparing treatment based only on PFMT with combined therapy (PFMT + ring pessary), the study by Cheung et al. [6] showed no significant difference between the therapies, but both treatments proved effective for the symptoms of prolapse. It is important to emphasize that in many cases, surgery is contraindicated and therefore treatment with pessaries becomes an effective alternative.

As seen in the present study, the use of vaginal pessaries may contribute to the improvement of symptoms of urinary loss. This finding remains in line with the improvement in symptoms observed in $76.9 \%(p<0.001)$ and $58.1 \%(p=$ 0.025 ) of women with degree III and IV prolapse, respectively, who presented urgency and stress UI after ring pessary therapy [14].

Another systematic review of studies regarding mechanical devices in the treatment of UI also found benefits of using the pessary in this dysfunction [17]. These authors, as well as those of this review, included the study by Richter et al. [12], who, in addition to showing improvements in urinary symptoms with the pessary use, found that this result may be even greater when associated with behavioural therapy. Sze and Hobbs [18] reported similar results of overactive bladder improvement when using pessary (19\%) and behavioural therapy (20\%).

Von Bargen and Patterson [19], when analysing the cost and benefit of stress $\mathrm{UI}$ treatments comparing pessary with surgical intervention, observed that surgery was the more cost-effective treatment provided a higher willingness to pay, while at a lower willingness to pay threshold, vaginal pessary turned out more cost-effective. However, this can be influenced by the individual patient's lack of knowledge regarding the device [20].

Regarding the instruments used to identify the dysfunctions, 4 applied the same questionnaire: PFDI-20, which was created by Barber et al. [21] and validated for Portuguese by Arouca et al. [22]. It was used in the 3 studies that evaluated the use of pessary in POP, as well as in the study assessing the use of pessary in UI. The questionnaire is widely referred to in the literature [23-26].

The 3 studies that evaluated the use of pessary in POP also employed the PFIQ and the Pelvic Organ Prolapse Quantitation system (POP-Q). The first one determines the impact of dysfunction in an individual and the second one quantifies the degree of POP [21, 27]. These two instruments can also be found in numerous studies [23, 26, 28-32].

The pessary is well tolerated by patients and despite its internal use, it does not present serious adverse effects, proving to be safe $[6,33]$. A systematic review evaluating the pessary in the treatment of prolapse showed that it could have a positive impact on the women's quality of life and improve the sexual function and body perception [34]. However, there perspective and whose main outcomes would be the quality of life and the satisfaction with the device usage.

The present review demonstrates the benefit of using vaginal pessaries in women who present with UI and POP, since it is possible to observe a reduction of these symptoms in this population. It is up to health professionals to choose the best type of pessary for each patient, as well as to advise them on the advantages that these devices can provide. This will result in a new possibility of treatment for these women, without a need for surgical interventions. Good methodological quality was also identified in most of the studies included in this review although some limitations were found.

\section{Limitations}

Among the limitations of the study, there is the methodological quality of the included papers. Owing to the evaluation with the PEDro scale, it was observed that some items were not satisfied, as a result of improper methods, mainly in relation to the blindness of the participants and evaluators. Therefore, controlled studies describing the use of pessary as a therapeutic method are suggested. They would allow to create effective strategies for the treatment of pelvic floor muscle dysfunctions, mainly aimed at adhering patients to conservative methods.

Also, the studies selected for the review did not mention the risks of bias. Randomized clinical trials are very prone to bias, which may result from collecting, analysing, interpreting, publishing, or reviewing data. Thus, analysing the risks of bias is important in order to make sure if the study answers the research question in an appropriate way.

\section{Conclusions}

With good methodological quality identified in most papers included in the study, they prove that the pessary is beneficial for the treatment of urinary incontinence and pelvic organ prolapse.

\section{Disclosure statement}

No author has any financial interest or received any financial benefit from this research.

\section{Conflict of interest}

The authors state no conflict of interest.

\section{Funding}

The presented study was funded by its researchers.

\section{References}

1. Wei JT, DeLancey JO. Functional anatomy of the pelvic floor and lower urinary tract. Clin Obstet Gynecol. 2004; 47(1):3-17; doi: 10.1097/00003081-200403000-00004.

2. Bo K, Frawley HC, Haylen BT, Abramov Y, Almeida FG, Berghmans B, et al. An International Urogynecological Association (IUGA)/International Continence Society (ICS) joint report on the terminology for the conservative and nonpharmacological management of female pelvic floor dysfunction. Int Urogynecol J. 2017;28(2):191-213; doi: 10.1007/s00192-016-3123-4.

3. Milsom I, Altman D, Lapitan MC, Nelson R, Sillén U, Thom D. Epidemiology of urinary (UI) and faecal (FI) incontinence and pelvic organ prolapse (POP). In: Abrams $P$, Cardozo L, Khoury S, Wein A (eds.), Incontinence. $4^{\text {th }}$ In- 
ternational Consultation on Incontinence. Paris: Health Publication Ltd; 2009; 37-111.

4. Dumoulin C, Hay-Smith EJ, Mac Habée-Séguin G. Pelvic floor muscle training versus no treatment, or inactive control treatments, for urinary incontinence in women. Cochrane Database Syst Rev. 2014;(5):CD005654; doi: 10.1002/14651858.CD005654.pub3.

5. Kammerer-Doak D, Svabik K, Bazi T. Variability in practice patterns in stress urinary incontinence and pelvic organ prolapse: results of an IUGA survey. Int Urogynecol J. 2017;28(5):735-744; doi: 10.1007/s00192-016-3174-6.

6. Cheung RY, Lee JH, Lee LL, Chung TK, Chan SS. Vaginal pessary in women with symptomatic pelvic organ prolapse: a randomized controlled trial. Obstet Gynecol. 2016;128(1):73-80; doi: 10.1097/AOG.0000000000001489.

7. Cundiff GW, Amundsen CL, Bent AE, Coates KW, Schaffer JI, Strohbehn K, et al. The PESSRI study: symptom relief outcomes of a randomized crossover trial of the ring and Gellhorn pessaries. Am J Obstet Gynecol. 2007;196(4):405.e1-e8; doi: 10.1016/j. ajog.2007.02.018.

8. Meriwether KV, Komesu YM, Craig E, Qualls C, Davis H, Rogers RG. Sexual function and pessary management among women using a pessary for pelvic floor disorders. J Sex Med. 2015;12(12):2339-2349; doi: 10.1111/ jsm.13060.

9. Drutz HP, Alarab M. Pelvic organ prolapse: demographics and future growth prospects. Int Urogynecol J Pelvic Floor Dysfunct. 2006;17 Suppl 1:S6-S9; doi: 10.1007/ s00192-006-0102-1.

10. Souto S, Palma T, Palma P. Femicushion ${ }^{\mathrm{TM}}$ : a new pessary generation - pilot study for safety and efficacy. Pelviperineology. 2016;35:44-47.

11. Barber MD, Walters MD, Cundiff GW. Responsiveness of the Pelvic Floor Distress Inventory (PFDI) and Pelvic Floor Impact Questionnaire (PFIQ) in women undergoing vaginal surgery and pessary treatment for pelvic organ prolapse. Am J Obstet Gynecol. 2006;194(5):1492-1498; doi: 10.1016/j.ajog.2006.01.076.

12. Richter HE, Burgio KL, Brubaker L, Nygaard IE, Ye W, Weidner A, et al. A trial of continence pessary vs. behavioral therapy vs. combined therapy for stress incontinence. Obstet Gynecol. 2010;115(3):609-617; doi: 10.1097/AOG.0b013e3181d055d4.

13. Kondo A, Yokoyama E, Koshiba K, Fukui J, Gotoh H, Yoshikawa $Y$, et al. Bladder neck support prosthesis: a nonoperative treatment for stress or mixed urinary incontinence. J Urol. 1997;157(3):824-827; doi: 10.1016/ S0022-5347(01)65055-9.

14. Ding J, Chen C, Song XC, Zhang L, Deng M, Zhu L. Changes in prolapse and urinary symptoms after successful fitting of a ring pessary with support in women with advanced pelvic organ prolapse: a prospective study. Urology.2016;87:70-75; doi:10.1016/j.urology.2015.07.025.

15. Haylen BT, Maher CF, Barber MD, Camargo S, Dandolu V, Digesu A, et al. An International Urogynecological Association (IUGA) / International Continence Society (ICS) joint report on the terminology for female pelvic organ prolapse (POP). Int Urogynecol J. 2016;27(4): 655-684; doi: 10.1007/s00192-016-3003-y.

16. Yeniel AÖ, Ergenoğlu MA, Meseri R, Aşkar N, Itil IM. How frequent are overactive bladder symptoms in women with urodynamic verification of an overactive bladder? J Turk Ger Gynecol Assoc. 2012;13(2):98-101; doi: 10.5152/jtgga.2012.11.
17. Lipp A, Shaw C, Glavind K. Mechanical devices for urinary incontinence in women. Cochrane Database Syst Rev. 2014;(12):CD001756; doi: 10.1002/14651858. CD001756.pub6.

18. Sze EH, Hobbs G. A retrospective comparison of ring pessary and multicomponent behavioral therapy in managing overactive bladder. Int Urogynecol J. 2014;25(11): 1583-1588; doi: 10.1007/s00192-014-2397-7.

19. Von Bargen E, Patterson D. Cost utility of the treatment of stress urinary incontinence. Female Pelvic Med Reconstr Surg. 2015;21(3):150-153; doi: 10.1097/SPV.0000000 000000159.

20. Brown LK, Fenner DE, DeLancey JO, Schimpf MO. Defining patient knowledge and perceptions of vaginal pessaries for prolapse and incontinence. Female Pelvic Med Reconstr Surg. 2016;22(2):93-97; doi: 10.1097/SPV. 0000000000000252.

21. Barber MD, Kuchibhatla MN, Pieper CF, Bump RC. Psychometric evaluation of 2 comprehensive conditionspecific quality of life instruments for women with pelvic floor disorders. Am J Obstet Gynecol. 2001;185(6):13881395; doi: 10.1067/mob.2001.118659.

22. Arouca MA, Duarte TB, Lott DA, Magnani PS, Nogueira AA, Rosa-E-Silva JC, et al. Validation and cultural translation for Brazilian Portuguese version of the Pelvic Floor Impact Questionnaire (PFIQ-7) and Pelvic Floor Distress Inventory (PFDI-20). Int Urogynecol J. 2016;27(7):10971106; doi: 10.1007/s00192-015-2938-8.

23. Tan AL, Hong L, Zhao $Y Z$, Jiang L. Influence of postoperative pelvic floor function on different surgical procedures of hysterectomy [in Chinese]. Zhonghua Fu Chan Ke Za Zhi. 2017;52(5):301-306; doi: 10.3760/cma.j.issn. 0529-567X.2017.05.003.

24. Leshem A, Shimonov M, Amir H, Gordon D, Groutz A. Effects of bariatric surgery on female pelvic floor disorders. Urology. 2017;105:42-47; doi: 10.1016/j.urology. 2017.03.003.

25. Abdullah B, Nomura J, Moriyama S, Huang T, Tokiwa S, Togo M. Clinical and urodynamic assessment in patients with pelvic organ prolapse before and after laparoscopic sacrocolpopexy. Int Urogynecol J. 2017;28(10):15431549; doi: 10.1007/s00192-017-3306-7.

26. Li-Yun-Fong RJ, Larouche M, Hyakutake M, Koenig N, Lovatt $\mathrm{C}$, Geoffrion R, et al. Is pelvic floor dysfunction an independent threat to sexual function? A cross-sectional study in women with pelvic floor dysfunction. J Sex Med. 2017;14(2):226-237; doi: 10.1016/j.jsxm.2016.11.323.

27. Bump RC, Mattiasson A, Bø K, Brubaker LP, DeLancey JO, Klarskov P, et al. The standardization of terminology of female pelvic organ prolapse and pelvic floor dysfunction. Am J Obstet Gynecol. 1996;175(1):10-17; doi: 10.1016/S0002-9378(96)70243-0.

28. Handa VL, Muňoz A, Blomquist JL. Temporal relationship between posterior vaginal prolapse and defecatory symptoms. Am J Obstet Gynecol. 2017;216(4):390. e1-390.e6; doi: 10.1016/j.ajog.2016.10.021.

29. Duan L, Lu YX, Shen WJ, Liu X, Liu JX, Zhang YH, et al. Long-term effectiveness of transvaginal high uterosacral ligament suspension [in Chinese]. Zhonghua Fu Chan Ke Za Zhi. 2017;52(6):363-368; doi: 10.3760/cma.j.issn. 0529-567X.2017.06.002.

30. Lo TS, Jaili S, Uy-Patrimonio MC, Karim NB, Ibrahim R. Transvaginal management of severe pelvic organ prolapse in nulliparous women. J Obstet Gynaecol Res. 2017;43(3):543-550; doi: 10.1111/jog.13234. 
31. Wang XQ, Zhu L, Li B, Tang X, Xu T. A prospective study of pessary treatment for pelvic organ prolapse and healthrelated quality-of-life [in Chinese]. Zhonghua Yi Xue Za Zhi. 2013;93(37):2982-2985; doi: 10.3760/cma.j.issn.03762491.2013.37.018.

32. Chan SS, Cheung RY, Lai BP, Lee LL, Choy KW, Chung TK. Responsiveness of the Pelvic Floor Distress Inventory and Pelvic Floor Impact Questionnaire in women undergoing treatment for pelvic floor disorders. Int Urogynecol J. 2013;24(2):213-221; doi: 10.1007/s00192-012-1827-7.

33. Maito JM, Quam ZA, Craig E, Danner KA, Rogers RG. Predictors of successful pessary fitting and continued use in a nurse-midwifery pessary clinic. J Midwifery Womens Health. 2006;51(2):78-84; doi: 10.1016/j.jmwh.2005.09.003.

34. De Albuquerque Coelho SC, de Castro EB, Juliato CR. Female pelvic organ prolapse using pessaries: systematic review. Int Urogynecol J. 2016;27(12):1797-1803; doi: 10.1007/s00192-016-2991-y. 